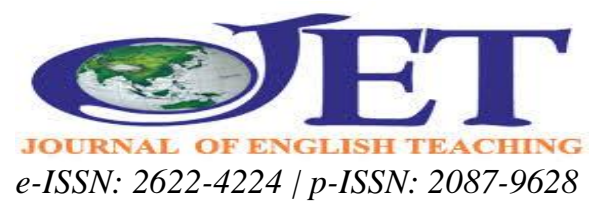

\title{
Using Drama in EFL Classroom
}

\author{
Luh Angelianawati \\ angelianawati@gmail.com \\ English Education Department, Faculty of Teacher Training and Education, \\ Universitas Kristen Indonesia, Indonesia
}

DOI: http://dx.doi.org/10.33541/jet.v5i2.1066

\begin{abstract}
Due to the many potential benefits and drama can offer in language learning, there has been a growing interest to use drama in ESL/EFL classrooms. However, the practice still causes many difficulties to both teachers and students due to several factors. This article reviews current theories and research findings on the use of drama in ESL/EFL teaching and learning to provide a better understanding of the use of drama to facilitate learning in EFL classrooms. It begins with current theories behind drama use in English learning. This section tries to clarify what drama is in the context of ESL/EFL, what benefits it offers, and what challenges teachers potentially meet. After that, the discussion focuses on a practical guideline for using drama in the classroom. It proceeds with a brief description of some useful drama techniques. The article ends by offering some concluding remarks.
\end{abstract}

Keywords: drama, EFL, role-play, mime, simulation

\section{INTRODUCTION}

With the increasing dominance of the communicative approach in the teaching of English as a second language (ESL) or English as a foreign language (EFL) since 1980s, literary works have grown teachers' interest to use literary works in the classrooms and increased the number of studies on how to effectively use them to promote students' performance (Pardede, 2011). The recent trend in ESL/EFL teaching indicates the necessity of integrating literature because it offers various benefits. Hadaway et al. (2002) suggested three benefits of literature use in EFL classrooms. First, it contextualizes the language. By reading literary works, students get familiar with the use of language in various situations. Second, by reading literary works, students will be provided with social factors embedded in different literary genres. Third, literary works offer the natural and meaningful application of language through the use of illustrations and descriptions. Parkinson and Thomas (2000: 9-11) listed ten potential benefits literature can provide in ESL/EFL learning and teaching: (1) cultural enrichment; (2) linguistic model; (3) mental training; (4) extension of linguistic competence; (5) authenticity; (6) memorability; (7) rhythmic resource; (8) motivating material; (9) open to interpretation; and (10) convenience. 
One of the most potential genres of literature to use for helping ESL/EFL learners learn effectively is drama. Communicative language teaching is essentially "a meaningbased, learner-centered approach to second or foreign teaching in which priority is put on fluency rather than accuracy and emphasizes more on the comprehension and production of messages rather than the instruction or correction of language construction" (Spada, 2007, p. 272). In such a learning approach, dramas are very suitable to use because the components of drama (actions, dialogues, and nonverbal languages) facilitate the students to actively participate in the language learning process. This will put the learners at the center of learning. By asking them to perform a drama, they can practice all language skills so that they learn to communicate in a contextualized way. Performing a drama also promotes cross-cultural understanding. Besides, as shown by some current studies like Dupre (2006) and Taskin-Can (2013), drama use also effectively develops creative thinking. Ozdemir and Çakmak (2008) posited that drama facilitates students of every level of education, advance their intellectual skills such as creativity, problem-solving, communication, socialization, and empathy and it provides individuals the chance for self-actualization, teamwork and sharing their responsibilities.

Due to the many potential benefits drama can offer, its use in EFL classrooms is highly recommended. Mattevi (2005) accentuated, “... the use of drama in the language classroom allows the teacher to present the target language in an active, communicative and contextualized way". Drama activities support the teacher to teach the four language skills. They also promote the study of some often ignored parts of language like pronunciation and gestures. The effectiveness of using drama is also supported by Moore (2002) who posited that "Drama has an important role to play in the personal development of our students. The skills and qualities developed by students in drama, such as teamwork, creativity, leadership, and risk-taking are assets in all subjects and all areas of life. Drama stimulates the imagination and allows students to explore issues and experiences in a safe and supportive environment."

Despite its great potentials and effectiveness, using drama in EFL class still causes many difficulties to both teachers and students due to several factors (Keshta, 2000; Royka, 2002; Mourtaga, 2004; Shakfa, 2012; Olaniyan, 2015). One of the ways to reduce the problems and difficulties is by getting a more comprehensive understanding of the use of drama, and this article is an attempt to fulfill it.

In this article, current theories and research findings on the use of drama in ESL/EFL teaching and learning are reviewed to provide a better understanding of the practice. The article begins with current theories behind drama use in English learning. This section tries to clarify what drama is in the context of ESL/EFL, what benefits it offers, and what challenges teachers potentially meet. After that, the discussion focuses on a practical guideline for using drama in the classroom. It is followed by a brief description of some useful drama techniques. The article ends by offering some concluding remarks.

\section{DISCUSSION}

\section{What is drama?}

In terms of language teaching, various authors have tried to define drama. Although these definitions seem different one from the other, they complete each other. First of all, Boulton (1968) stated that drama is "not really a piece of literature for reading. It is the literature that walks and talks before our eyes"' (p. 3). This definition emphasizes 
that text of a drama is meant to be transformed into actions, dialogues or sights. However, to act out a drama, the performer should first carefully read and analyze the text. Thus, if students are assigned to perform a drama, they must start by dealing with the language structures and language items of the work. The results of the reading and analysis are then used to communicate in a contextualized setting.

Via (1987) defined drama as "communication between people" (p. 110) that conveys meaning. This definition tends to emphasize that the text of a drama should be regarded as a material for conducting meaningful oral communication. Hubbard, Jones, Thornton and Wheeler's (1986), in addition to creativity, also emphasized the oral side of drama. They define it as "a wide range of oral activities that have an element of creativity present" (p. 317).

A more detailed definition was proposed by Holden (1981). She viewed drama as synonymous with the idea of "let's pretend"; which "asks the learner to project himself imaginatively into another situation, outside the classroom, or into the skin and persona of another person" (p. 1), where the focus is on "doing rather than on the presentation" (p. 8). This definition indicates that drama is any activities in which the learners are asked to either to portray themselves or portray someone else in an imaginary situation. The activities could be done alone by a single student or by a student with one or more classmates. Since the focus is on doing, not the on the presentation, the priority of performing drama in the language classroom is not for a show before the audiences but for facilitating the students to interact with other people and practice their store of language for communicating in a meaningful manner. This is in line with Maley and Duff's (1984) views that dramatic activities in the language classroom are not the performance of plays before audiences, but for activities to develop language competence and imagination.

Although the employment of drama in the English classrooms is basically for developing language competence and imagination, not for exhibition, teachers should never discourage their students to act out their scenes to the rest of the class or a larger audience if they wish to. Supporting them to perform the rehearsed drama activities can promote higher enthusiasm and creativity.

\section{Benefits of Using Drama in EFL Classrooms}

Since drama is essentially an act of communicating meaning, students are actively engaged while learning through drama. They take part in conversations or practices that require them to use their imagination and foreign language in contextualized situations. When such activity is planned well enough, students will also find it interesting. Such motivating learning activity will surely encourage and help them develop their language skills and to acquire the language more deeply and naturally. Owens and Barber (1998) argued that drama is not the only right technique to learn, but it is one of the ways that keep the lessons interesting because it attracts students' attention so that they do not remain quietly seated. It also facilitates variation in the learning process since it can employ different learning styles, functions and group work forms. Clipson-Boyles (1998) accentuated that although teaching English with drama mostly assists listening and speaking, it also produces processes related to writing and reading. In short, the employment of drama in the classroom provides the students with an opportunity to learn by doing and experiencing rather than only inactive listening and repeating.

Several authors have outlined the benefits of using drama in language teaching. Boudreault (2010) summarized that drama use in language teaching facilitates: (1) the 
acquisition of meaningful, fluent interaction in the target language; (2) the assimilation of a whole range of the features of pronunciation and prosody in a contextualized and interactional fashion; (3) the acquisition of new fully contextualized vocabulary and structure; (4) an improved sense of students' confidence in their ability to learn the target language; (5) an opportunity to develop the students' imagination; (6) an opportunity to increase independent thinking; (7) exercises in critical and creative thinking; (8) the advancement of skills of cooperation and social awareness and understanding; and (9) the chance for a healthy release of emotion in a safe setting which can work to relieve the tension of learning in a second language.

Based on their literature review, Charles and Kusanagi (2007) stated that the drama approach offers many benefits in language education because drama (1) directs students' awareness of how people communicate in different communication modes and improves communicative behaviors; (2) helps students develop their English abilities: speech acts; pronunciation and intonation, and discourse strategies; provides a genuine context for communication and makes the target language more real.

Additionally, based on his observations of the use of simple drama activities with students and in teacher-in-service workshops, Culham (as cited in Albalawi, 2014) summed up the drama employment in language learning as follows: (1) Students are able to express themselves in ways other than through words; (2) Drama activities offer community-building opportunities in a classroom where there are students of varying levels of language proficiency; (3) Teachers are also able to use non-verbal cues to demonstrate caring and concern for students in a way that more formal language instruction does not allow, bound as it is by the physical constraints and the pressure to understand; (4) Non-verbal drama activities provide an excellent means of releasing the stress of language learning; (5) Students, often hesitant to speak out, can become confident when the language expectation is removed entirely; (6) "Total Physical Response is enhanced through drama activities; (7) In all drama work, power dynamics shift as the teacher becomes a participant alongside the students; (8) Non-verbal drama activities transfer directly to verbal ones, and subsequent verbal interchanges are triggered by these non-verbal activities" (p. 54).

In addition to these views, several current empirical studies also proved the benefits of using drama in ESL/EFL classrooms. The study of Matsuzaki (2005) focusing on adapting the drama method in the English class of upper-grade elementary students in Japan revealed that the use of drama enhanced the students' motivation for learning English and lead to greater sociocultural awareness. O'Gara's (2008) study which investigated the effectiveness of drama for teaching verb tenses in a secondary school setting in Milan, Italy revealed that teaching language tenses through drama was more effective than using traditional methods. Based on the results of his study, Sam (1990) concluded that "Drama helps to extend, retain and reinforce vocabulary and sentence structure through role-play and communication games" (p. 86).

In an experimental study involving 60 intermediate EFL students enrolled in English drama II classes in Iran, Gorjian, Moosavinia, and Japripour (2010), the control group was directed to read the literature; while the experimental group learned the content indirectly through role-playing and dramatic activities. The post-test results showed a significant difference between the two groups, for the experimental group mean-score was 9.5 points higher than that of the control group. In addition, Rew and Moon (2013) investigated the use of scripted play - a kind of dramatized storytelling among Korean primary school students in learning some targeted English expressions. 
The results indicated that (1) English drama was effective to employ for learning specific English expressions; (2) both male and female students got similar benefits; (3) drama was beneficial for both students with high and low English proficiency; and (4) students can use the expressions learned in drama in different situations.

\section{Challenges of Using Drama in EFL Classrooms}

Just like any other teaching method, apart from the significant advantages described previously, the use of drama can also have some disadvantages. Even though these disadvantages are less in number compared to the advantages, they are worth considering as anticipation so that they can be prevented or be properly solved. First, shy students may find drama frustrating. To solve this problem, the teacher should find a way to help such students overcome their fears and shyness so that they are willing to actively participate. Second, the teacher often needs extra time to plan the lessons rigorously. Wessels asserted: "... drama requires meticulous planning and structuring." and also "create a learning situation which will ensure a constant supply of stimuli to the students, which will keep them active and alert." (Wessels, 1987: 15). The teacher, therefore, must be always well prepared for the lessons. They should anticipate if the drama happens to last too long or to end too early.

The third disadvantage is that correcting students' mistake during a drama performance could be difficult. Mistakes are a natural part of language learning. Yet, they should learn from the mistakes they make. Concerning this, the teacher should employ such feedback techniques for correcting mistakes which do not interrupt and discourage the students during the drama performance. Finally, discipline should be kept during lessons to avoid disorder and misinterpretation. During a dramatic activity, it is possible that the class becomes noisy. Some students could possibly scream or shout. To anticipate such conditions, the teacher should have techniques to settle the students down and avoid them to change the dramatic activities into a chaotic situation.

\section{Practical Guideline for Integrating Drama in Language Learning}

Like any other language learning activities, drama requires proper preparation before it is integrated into a lesson. Holden (1982) proposed the following five-point plan for integrating drama activities into the lesson. First of all, the teacher clarifies the idea, theme, or problem to the students and arranges any preliminary work to ensure that the students exactly know what to do. Secondly, the students discuss in groups, plan what they are going to do and precisely aware the plan should be executed. Then, they try out in groups with various interpretations until they find the best one. The fourth stage could concern with students showing their interpretation or solution to one or more other groups. Finally, the students discuss their show or solution in groups or with the rest of the class. This discussion can serve as a form of valuation for the students of their work. Such evaluation, which carried out in the target language, provides more opportunity for the students to practice their target language and to feel that the scene they have just been working is satisfactory. The discussion session could be moderated either by the teacher or by a nominated student. It could also be conducted in groups under the guidance of a selected group leader, and this would undoubtedly intensify the amount of individual student talking time.

\section{Some Useful Drama techniques for EFL Learning}


Dramas include various types of language teaching activities, e.g. drama game, roleplay, mime, stimulation, scripted play, and improvisation. The first five techniques are recommended to use before the students are assigned spontaneous activities, like improvisation. To run them effectively, the students need to be prepared in advance. Each of these techniques is briefly described in the next section.

\section{Drama Game}

As a teaching approach, games are appropriate for every levels and age. Brandes and Phillips (1990) described drama games as "short activities that may have different objectives: they can be ice-breakers or warm-up activities; we can use them to introduce a new topic, or to relax, or to encourage students to interact, or to make them feel more confident, etc. For instance, to teach the students how to give direction, two children can play a "Blind Man" drama game. One of them acts as if he is blind the other student direct him by saying "Turn right in five steps. Turn right again I for steps and turn left ..."

\section{Role-Play}

The meaning of the term role-play could be interpreted from the two words that form it. The word "role" indicates that the individual taking part in the activity is playing a part (his/her own or somebody else's) in a particular condition. The word 'play' means that the role is taken on in a safe environment in which students are as inventive and playful as possible." (Ladousse, 2002: 5). In short, role-play is essentially an imitation the reality in which the students are required to act and speak properly in line with the contexts and their "roles". Yardley-Matwiejczuk (1997) argued that role play is a way of deliberately constructing an approximation of aspects of a 'real-life' episode or experience, but under 'controlled' conditions where much of the episode is initiated and/or defined by the experimenter or therapist" (p. 1). It can be a very short action with a minimum setting preparation and one actor, or it may last longer with many accessories and actors. Paulston (as cited in Lee, 2015) defined role-play as exercises in which a student has been assigned a fictitious role from which he has to improvise some kind of behavior towards the other role characters in the exercise.

Blatner (2009) argued that role play assists students to become more interested and involved, especially by applying knowledge to action, by solving problems, evaluating alternatives and looking for original solutions. Role-play enables students to develop a wide range of abilities, such as initiative, self-confidence, group work and communication in general. Thus, role-play makes students ready not only for communicating in the target language but also in its cultural and social context (Kodotchigova, 2002).

To succeed in the use of role-playing in language learning, Kodotchigova (2002) proposed seven steps to follow. First, the teacher has to create a situation which meets the students' needs, interests, age, and previous experience. Second, the teacher develops the role play in line with the students' level of competence in the foreign language. Third, the teacher analyzes the linguistic factors students should prepare to properly to get involved in the performance and let them acquire them. In the fifth step, the students are given precise role descriptions and information. Sixth, such roles are assigned and the roleplay is represented. Finally, the follow-up activity is dedicated to debriefing, in which students can express their opinion about the performance. 


\section{Mime}

Mime as "a non-verbal representation of an idea or story through gesture, bodily movement, and expression" (Dougill, 1987, p. 13). In mime, the students use movement, gestures, and expression to act a story or some ideas without using any words. Since it involves non-verbal languages, it provides the advantage that students can perform comfortably as are performing in front of their classmates without worrying about language. It is also fun and, thus, can be easily employed as a warm-up exercise. Since it employs a visual component, it helps students to memorize language for memory is extremely reinforced by visual associations.

Although words are not used during mime, the verbal language is employed when an explanation is required, both with the teacher's instructions and students' debates, which are made in pairs or groups (Dougill, 1987). During the discussion, the foreign language can be used for assessing and evaluating the performance.

\section{Simulation}

Buckner (1999) defined simulation as, "an intensive, interactive experience in which the content and roles assumed by participants are designed to reflect what people encounter in specific environments" (p. 1). Therefore, simulations create an environment in which the participants are involved in a personally meaningful activity. Sturtridge (1984) clarified that "in a simulation, the learner is given a task to perform or a problem to solve; the background information and the environment of the problem are simulated" (p. 128). Sometimes a role play and a simulation tend to be confused with each other. Livingstone (1985) distinguishes them by stating that, different from role-playing, "simulations need not stick so closely to real life. The essential point is that the student brings his personality, experience and opinions to the task" (p. 1). When a group of students is assigned to be a football team discussing a strategy to win a game, they are performing a simulation. In that activity, realia, such as a football strategy board is necessary.

The use of simulation enables the students to see the usefulness of the language they are learning. Thus, it helps the teacher construct the opportunity for the students to have more chances to communicate and practice their language abilities in the real world with their engagement and enjoyment.

\section{Scripted Play}

A scripted play is a scene or sketch that is acted out by pupils in front of their classmates and the teacher. The sketches can be either original or written by students. It is a great way to reinforce the use of the foreign language because, before it is performed, the script should be read, in a group or individually. Students should also analyze and discuss it and prepare the equipment they need to act it out. After that, they must memorize the script and interpret it based on the director's guidance. Since the preparation and the performance extensively require language uses, scripted play provides the opportunity to improve speaking and interaction with other people as well as enriches the learners' vocabulary and functional language like agreeing or disagreeing, apologizing, refusing, offering help, etc. (Scrivener, 1994: 69).

\section{Improvisation}

Improvisation is a spontaneous action without any script or rehearsal with minimal instruction or framework from the teacher. In improvisation, the students employ their 
ideas and imaginations to collaborate. Wessels (1987) believed that "... improvisation taps the students' already existing command of the language and tests their communicative strategies" (p. 85). They are also encouraged to actively participate. The teacher can provide exercises with the use of improvisation involving the whole class or small groups. To do so, he or she should create the context in which the students are involved. Having got the theme, the students can spontaneously participate in the activity. Yet, students should be prepared for improvisation activities with a suitable warm-up for "even native speakers can find improvisation quite daunting without adequate warm-up activities" (Wessels, 1987, p. 85).

\section{CONCLUSIONS}

The discussions in the previous sections have shown the many potentials of using drama in EFL classrooms. Since drama is essentially an activity of portraying oneself or other people through actions and words, in language classrooms it promotes students to use and develop their language skills, thinking skills, and creativity in an interesting way. Another factor which makes drama beneficial to use is that it promotes student-centered learning because to perform a drama often necessitates several stages of team preparation, during which the students cooperate with other students. Besides getting more talking time during performance preparation, it also improves students' maturity and motivation. Discussions can be even conducted after a performance. This will also provide each student to practice communicating in the target language in a natural context.

Various literature reviews have shown that using drama offers many benefits. Based on these, several authors highly recommended the use of drama in EFL classrooms. Also, many current empirical studies clarified the benefits of using drama in language education. Like any other teaching approaches, a drama also has some potential difficulties. However, using good preparation, they could be anticipated, reduced, or avoided.

To succeed in the use of drama, the teachers should first analyze what section of the lesson can be interestingly learned through drama. Based on the students' readiness, the teacher should also decide the best type of dramatic activity to use: drama game, or role-play, or mime, etc. In addition, the teacher should also make proper preparation, and this article includes a general guideline proposed by Holden to do this.

\section{REFERENCES}

Albalawi, B.R.(2014). Effectiveness of Teaching English Subject using Drama on the Development of Students' Creative Thinking. IOSR Journal of Research \& Method in Education, 4(6), pp. 54-63. Retrieved October 2015 from http://www.iosrjournals.org/iosr-jrme/papers/Vol-4\%20Issue-6/Version1/H04615463.pdf

Blatner, A. (2009). Role-Playing in Education. Retrieved March 2013 from http://www.blatner.com/adam/pdntbk/rlplayedu.htm

Boudreault, C. (2010). The Benefits of Using Drama in the ESL/EFL Classroom. The Internet TESL Journal, 16(1). Retrieved April 2015 from http://iteslj.org/Articles/Boudreault-Drama.html

Brandes, D. \& Phillips, H. (1990). Gamesters' handbook, Cheltenham: Stanley Thornes. 
Boulton, M. (1968). The anatomy of drama (3rd ed.). London: Routledge and Kegan Paul Ltd.

Buckner, M. (1999). Simulation and role-play: presentation skills and games. Alexandria, VA: ASTD.

Charles, D., Kusanagi, Y. (2007). Using drama to motivate EFL students: Building classroom communities and student identities. In K. Bradford-Watts (Ed.), JALT 2006 Conference Proceedings. Tokyo: JALT.

Clipson-Boyles, S. 1998. Drama in primary English teaching. London: David Fulton Publishers Ltd.

Dougill, J. (1987). Drama activities for language learning. London: Macmillan

Dupre, B. J. (2006). Creative Drama, Playwriting, Tolerance, and Social Justice”. Ph.D. Dissertation, Language, Literacy, and Sociocultural Studies, The University of New Mexico 2006. UMI Number: 3220936

Gorjian, B., Moosavinia, S. R., \& Jabripour, A. (2010). Dramatic performance in teaching drama in EFL contexts. The Electronic Journal of Teaching English as a Second Language (TESL-EJ), 13(4), pp. 1-13.

Hadaway, N. L., Vardell, S. M., \& Young, T. A. (2002). Literature-based instruction with English language learners, $K-12$. Boston: Allyn and Bacon.

Holden, S. (1981). Drama in language teaching: Longman handbook for language teachers. London, Great Britain: Spottiswoode Ballantyne Ltd.

Mattevi, Y. (2005). Using Drama in the classroom: the educational values of theatre in second language acquisition. Ph.D. Dissertation, Stony Brook University. UMI number: 3189394

Keshta, A. S. (2000). Alternative Approaches for Teaching English Literature to Undergraduate Students in Gaza Strip. Ph.D. Dissertation, University of Houston. Retrieved July 2015 from https://www.researchgate.net/publication/36227986_Alternative_approaches_for_ teaching_English_literature _to_undergraduate_students_in_Gaza_Strip.

Kodotchigova, M. A. (2002). Role Play in Teaching Culture: Six Quick Steps for Classroom Implementation. The Internet TESL Journal, 7(8). Retrieved March 2013 from http://iteslj.org/Techniques/Kodotchigova-RolePlay.html

Lee, S. (2015). Revisit Role-Playing Activities in Foreign Language Teaching and Learning: Remodeling Learners' Cultural Identity? Electronic Journal of Foreign Language Teaching, 12(1), pp. 346-359.

Livingstone, C. (1985). Role Play in Language Learning. Harlow: Longman.

Moore, A. (2002). Drama for secondary schools - study guide. Retrieved July 2015 from http://www.universalteacher.org.uk/drama/drama.htm\#why

Mourtaga, K. (2004). Investigating Problems among Palestinian Students. Published Ph.D. Dissertation, London: Author House.

O'Gara, P. (2008). "To be or have not been: Learning language tenses through drama". Issues in Educational Research, 18(2), pp. 156-166.

Olaniyan, M.E. (2015). The Challenges and Prospects of Teaching and Learning Dramatic Arts in Tertiary Institutions in Nigeria. African Research Review, 9(3), pp. 113-124. http://dx.doi.org/10.4314/afrrev.v9i3.10

Owens, A. and Barber, B. 1998. Draama toimii. (transl. Kaijanen, J-P. And Korhonen, P.) Helsinki: JB-kustannus.

Ozdemir, S.M. and Çakmak, A. (2008). The effect of drama education on prospective teachers' creativity. International Journal of Instruction, 1(1), pp. 13-30. 
Pardede, P. (2011). Using Short Stories to Teach Language Skills. Journal of English Teaching, 1(1), pp. 15-27.

Parkinson, B. and Thomas, H.R. (2000). Teaching literature in a second language. Edinburgh: Edinburgh University Press.

Rew, S. and Moon, Y. (2013). The effect of using drama on the learning of target expressions for primary students. The Journal of Asia TEF, 10(4), 215-239

Royka, J.G. (2002). Overcoming the Fear of Using Drama in English Language Teaching. The Internet TESL Journal, 8(6). Retrieved March 2015 from http://iteslj.org/Articles/Royka-Drama.html

Sam, W.Y. (1990). Drama in teaching English as a second language: A communicative approach. The English Teacher, 9. Retrieved March 2, 2004, from http//:www.melta.org.mv/html

Scrivener, J. (1994) Learning teaching: A guidebook for English language teachers. London: Macmillan

Shakfa, M. (2007). Difficulties Facing English Department Junior and Senior Students at the Islamic University of Gaza in Learning Drama. Unpublished Master Thesis, Islamic University of Gaza, Palestine. Retrieved September 2015 from http://library.iugaza.edu.ps/book_details.aspx?edition_no=82472

Spada, N. (2007). Communicative language teaching: Current status and future prospects. In Cummins, J. and Davison, C. (Eds.), International handbook of English language teaching (pp.271-288). New York: Springer

Sturtridge, G. (1984). Procedures and techniques. Role-play and simulations. In Johnson, K. and Morrow, K. (Eds.), Communication in the Classroom (pp. 126130). London: Longman.

Taskin-Can, B. (2013) The Effects of Using Creative Drama in Science Education on Students' Achievements and Scientific Process Skills". Ilkogretim Online. 12(1), pp. 120-131.

Via, R. A. (1987). "The magic if" of theater: Enhancing language learning through drama. In W.M. Rivers (Ed.), Interactive language teaching (pp. 110-123). Cambridge: Cambridge University Press.

Wessels, C. (1987). Drama. Oxford: Oxford University Press. 